\title{
Detailed hemodynamics of fulminant myocarditis caused by COVID-19
}

\author{
Teruhiko Imamura ${ }^{1}[$
}

Received: 26 April 2020 / Accepted: 18 May 2020 / Published online: 24 May 2020

(c) Springer-Verlag GmbH Germany, part of Springer Nature 2020

To the editor:

The association between coronavirus disease 2019 (COVID19) and cardiovascular diseases is of great concern. Zeng and colleagues reported for the first time a patient with COVID19 complicated with fulminant myocarditis [1,2]. Several concerns should improve the implication of their finding.

The electrocardiogram on admission indicates right ventricular loading, given elevated $R$ waves and strain pattern with inverted $T$ wave in V1-2 leads, as well as deep S waves in V5-6 leads, in addition to left atrial loading, given biphasic $\mathrm{P}$ wave in V1 lead. Invasive right heart catheterization would have been useful to more accurately assess right ventricular function, using central venous pressure, right ventricular stroke work index, and pulmonary artery pulsatility index [3]. Hemodynamic monitoring using right heart catheterization might also have clarified the mechanism of hemodynamic deterioration on day 29. Furthermore, a concomitant endo-myocardial biopsy from the right ventricular septum would have contributed to pathological diagnosis concluding definite causality of COVID-19: direct myocardial injury or indirect immune-associated myocardial depression. Complete recovery of myocardial function in their case might support the latter causality.

Recently, percutaneous minimal axial-flow left ventricular assist device is considered concomitantly with extracorporeal membrane oxygenation for biventricular unloading (i.e., ECPELLA) [4]. If the patient already had a severe biventricular failure on admission, such a more intensified mechanical circulatory support might have been recommended, instead of extracorporeal membrane oxygenation alone. On the contrary, we should understand that such intensified mechanical therapy increases the risk of devicerelated comorbidities including bleeding, thrombosis, and

Teruhiko Imamura

teimamu@med.u-toyama.ac.jp

1 Second Department of Medicine, University of Toyama, 2630 Sugitani, Toyama, Toyama 930-0194, Japan infection. The appropriate device selection and estimated support length for those with COVID-19-related fulminant myocarditis remain unknown.

Nevertheless, we should consider also the challenging situation in the management of COVID-19 patients using personal protective equipment and restrictive medical resources, and such optimal strategies might not always be realistic. I again congratulate the authors' devoted management.

\section{Compliance with ethical standard}

Conflict of interest None.

\section{References}

1. Zeng JH, Liu YX, Yuan J, Wang FX, Wu WB, Li JX, Wang LF, Gao H, Wang Y, Dong CF, Li YJ, Xie XJ, Feng C, Liu L. First case of COVID-19 complicated with fulminant myocarditis: a case report and insights. Infection. 2020. https://doi.org/10.1007/ s15010-020-01424-5.

2. Yancy CW, Jessup M, Bozkurt B, Butler J, Casey DE Jr, Drazner MH, Fonarow GC, Geraci SA, Horwich T, Januzzi JL, Johnson MR, Kasper EK, Levy WC, Masoudi FA, McBride PE, McMurray JJ, Mitchell JE, Peterson PN, Riegel B, Sam F, Stevenson LW, Tang WH, Tsai EJ, Wilkoff BL. 2013 ACCF/AHA guideline for the management of heart failure: executive summary: a report of the American College of Cardiology Foundation/American Heart Association Task Force on practice guidelines. Circulation. 2013;128:1810-52.

3. Ammirati E, Veronese G, Cipriani M, Moroni F, Garascia A, Brambatti M, Adler ED, Frigerio M. Acute and fulminant myocarditis: a pragmatic clinical approach to diagnosis and treatment. Curr Cardiol Rep. 2018;20:114.

4. Tschope C, Van Linthout S, Klein O, Mairinger T, Krackhardt F, Potapov EV, Schmidt G, Burkhoff D, Pieske B, Spillmann F. Mechanical Unloading by Fulminant Myocarditis: LV-IMPELLA, ECMELLA, BI-PELLA, and PROPELLA Concepts. J Cardiovasc Transl Res. 2019;12:116-23. 